
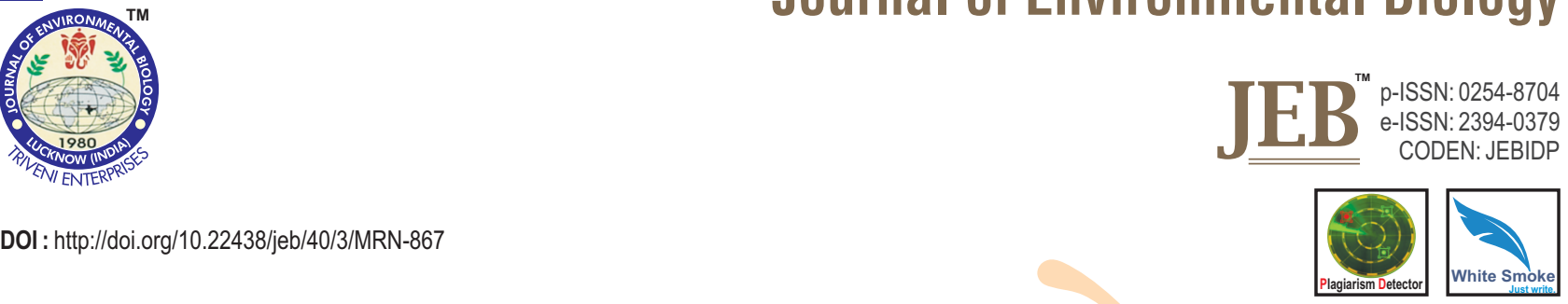

\title{
In-vitro DNA and cell damage induced by 5-chloro-2- methyl-4-isothiazolin-3-one (CMIT) and suppressive effect of selected phytochemicals against CMIT toxicity
}

\begin{tabular}{|c|c|c|c|}
\hline Paper received: 26.02.2018 & Revised received: 31.07.2018 & Re-revised received: 28.09.2018 & Accepted: 19.11 .2018 \\
\hline
\end{tabular}

\section{Authors Info \\ Y.E. Jeong ${ }^{1}$ and M.Y. Lee ${ }^{1,2 *}$ \\ 'Department of Medical Science, \\ College of Medical Sciences, \\ Soonchunhyang University, 22, \\ Soonchunhyang-ro, Asan, \\ Chungnam-31538, \\ Republic of Korea \\ ${ }^{2}$ Department of Medical Biotechnology, College of Medical Sciences, \\ Soonchunhyang University, 22, \\ Soonchunhyang-ro, Asan, \\ Chungnam-31538, \\ Republic of Korea \\ *Corresponding Author Email : miyoung@sch.ac.kr}

\section{Edited by \\ Dr. Saurabh Chandra}

Reviewed by

Dr. R.B. Raizada

Dr. S.J.S. Flora

\section{Abstract}

Aim : The aim of the present study was to measure in-vitro DNA and cell damage induced by 5-chloro-2methyl-4-isothiazolin-3-one (CMIT), one of the humidifier disinfectants, and to investigate the suppressive effect of various phytochemicals against CMIT toxicity.

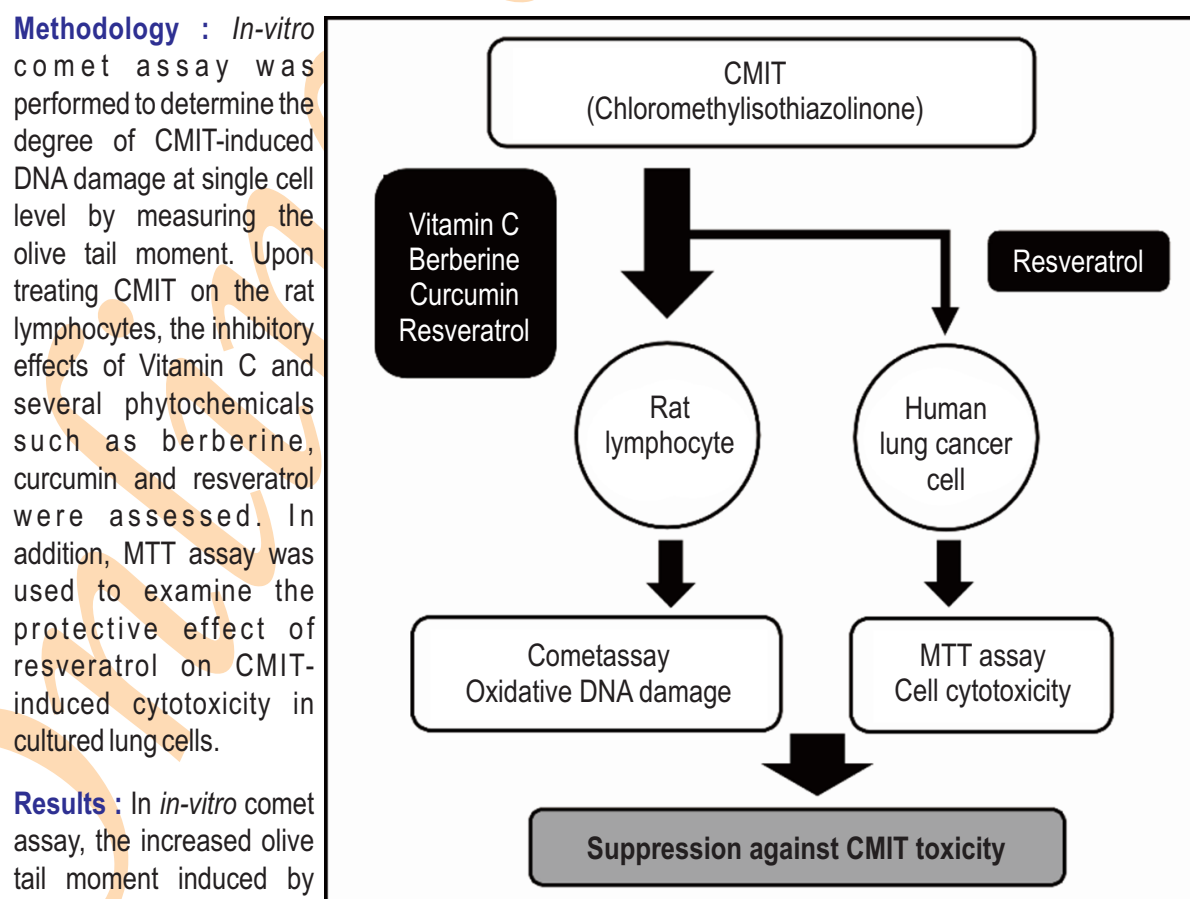

CMIT was effectively CMIT was effectively

inhibited by Vitamin C, berberine, curcumin and resveratrol treatment. Especially, resveratrol showed the best suppressive effect against DNA damage by CMIT. In MTT assay, resveratrol also showed significant suppressive effect against cytotoxicity induced by CMIT in cultured lung cells.

Interpretation : Phytochemicals such as Vitamin C, berberine, curcumin and resveratrol can be utilized in the development of preventive or therapeutic compositions against the injury caused by CMIT toxicity.

Key words: Chloro methyl isothiazolinone, Cometassay, DNA damage, MTT assay, Phytochemicals

How to cite : Jeong, Y.E. and M.Y. Lee: In-vitro DNA and cell damage induced by 5-chloro-2-methyl-4-isothiazolin-3-one (CMIT) and suppressive effect of selected phytochemicals against CMIT toxicity. J. Environ. Biol., 40, 335-341 (2019). 


\section{Introduction}

Isothiazolone biocide, 5-chloro-2-methyl-4-isothiazolin3-one (CMIT), also referred as methylchloroisothiazolinone, is used in a wide range of personal care products with a broadspectrum biocide efficacy (Nagorka et al., 2015). It is also used as a preservative with antibacterial and antifungal effect, with the registered tradename Kathon CG in combination with methylisothiazolinone (MIT). The most widely used biocide of isothiazolinones is CMIT and MIT mixture (3:1), showing effective killing against most bacteria, yeast and fungi (Frenzel et al., 2011).

Recently, significant peripheral airway dysfunction has been reported in children with high-level inhalation exposure to a mixture of CMIT/MIT (Cho et al., 2017). CMIT/MIT mixture has been registered as a secondary inhalation toxicant by US Environmental Protection Agency (EPA). Approximately 900 victims have been reported to suffer from severe lung diseases, associated with exposure to humidifier disinfectant containing polyhexamethylene guanidine (PHMG) and oligo (2-(2-ethoxy) ethoxyethyl guanidinium chloride (PGH) as well as CMIT/MIT in Korea. In addition, inhalation toxicities together with positive findings of in-vitro genotoxicity studies have been reported in toxicological reports for humidifier disinfectant (Kim and Paek 2016). As a result, CMIT/MIT mixture has been prohibited in all spray type of products in Korea, due to the potential health concerns associated with possible lung toxicity, allergy and neurotoxicity. Recently, Kim et al. (2017) reported positive association between CMIT/MIT exposure and death in a mouse model.

In cosmetic products, CMIT and MIT are two of the most key contact allergens. Dermal irritation occurs commonly in products with CMIT and CMIT/MIT mixtures, but not as common in products with only MIT (Maio et al., 2012). CMIT is more potent than MIT in lymphocyte proliferation as a skin sensitizer (Botham et al., 1991) and in binding proteins and triggering auricular lymph node cell proliferation (Potter and Hazelton, 1995). Moreover, CMIT is mutagenic in nature whereas MIT is not (Conner et al., 1996). The exposure to liquid MIT showed significant neurotoxicity in cerebral cortex cells, whereas the exposure did not show notable neurotoxicity in animals through drinking water (He et al., 2006; Poon et al., 2011; Pelletier et al., 2014). Recently, MIT toxicity has been reported to induce cell death and inflammatory response via DNA damage and nuclear envelope rupture (Park et al., 2018). In addition, CMIT is not considered as a carcinogen by International Agency for Research on Cancer (IARC) (Kahrilas et al., 2014), but chronic and high exposure can cause fatal symptoms.

Comet assay, also referred to as single cell gel electrophoresis assay, is one of the most sensitive and accurate techniques to measure oxidative DNA damage in eukaryotic cells. At the same time, it is also useful intesting DNA repair after direct and oxidative DNA damage (Collins, 2004). It has sensitive detection limit for low levels of DNA breaks in small number of cells, although the mechanism underlying the genotoxic and repair activity by the inducers cannot be identified through comet assay. In addition, further follow-up studies including animal tests are needed to reduce the false positive results frequently shown in in-vitro genotoxicity testing (Kirkland et al., 2007).

The reports on CMIT toxicity at DNA and cellular level is limited. Moreover, specific natural products that reduce CMIT toxicity have not been addressed yet, thus, there is a great need to find the agents to reduce, prevent or ameliorate CMIT toxicity. Phytochemicals, alone or in combination with others, have attracted notable attention to prevent the onset of a wide variety of chronic diseases including cardiovascular impairments, cancer and metabolic abnormalities (Upadhyay and Dixit, 2015). In this investigation, CMIT toxicity was assessed in-vitro in terms of DNA damage and cytotoxicity, and the suppressive effects of selected phytochemicals on CMIT toxicity was also investigated.

\section{Materials and Methods}

Preparation of lymphocytes: Male Sprague Dawley rats weighing 200 250g were purchased from the Orient Bio Co. Ltd. (Seongnam, Korea). Room temperature was maintained at $20 \pm$ $2^{\circ} \mathrm{C}$ and the relative humidity at $60 \pm 10 \%$. A200 $\mu$ l of whole blood from Sprague Dawley rats was added to $800 \mu$ of phosphatebuffered saline (PBS) and layered onto $200 \mu \mathrm{l}$ of Histopaque 1077 (Sigma-Aldrich, St. Louis, MO). After centrifugation at 1,500 rpm for $5 \mathrm{~min}$ at room temperature, the lymphocytes were collected from the buffy-coat layer and washed with PBS. To examine the protective effect of phytochemicals, a $400 \mu$ of whole blood from Sprague Dawley rats was used. Comet assay using rat blood was conducted with the approval of Animal Research Ethics Committee at Soonchunhyang University (SCH15-0007).

CMIT treatment: 5-chloro-2-methyl-4-isothiazolin-3-one CMIT (Cayman chemical company, Michigan, USA) was diluted to 10 $\mu \mathrm{g} \mathrm{ml}^{-1}$ in PBS. To examine the protective effect of Vitamin $\mathrm{C}$ and phytochemicals against DNA damage, 1 7 $\mathrm{g} \mathrm{m} \mathrm{m}^{-1}$ of Vitamin $\mathrm{C}$, berberine, curcumin and resveratrol was directly added to the lymphocytes which were treated for $30 \mathrm{~min}$ at $37^{\circ} \mathrm{C}$ before CMIT treatment. Vitamin $\mathrm{C}$ and berberine were dissolved in water and resveratrol and curcumin, which had low solubility in water, were dissolved in dimethyl sulfoxide (DMSO). All materials were diluted in PBS to ensure that the concentration of DMSO in the cells did not exceed $0.5 \%$.

Determination of DNA damage by comet assay: Alkaline comet assay was performed according to the method of Singh et al. (1988) with slight modification to evaluate CMIT-induced DNA damage and protective effect of phytochemicals. The lymphocytes were mixed with $75 \mu \mathrm{l}$ of $0.7 \%$ low-melting-point agarose (LMA) and placed onto slides coated with $1 \%$ normalmelting-point agarose (NMA) and then allowed to solidify over 30 min at $4^{\circ} \mathrm{C}$. After solidification, the slides were covered with $100 \mu \mathrm{l}$ of $0.7 \%$ LMA. When the last applied agarose had solidified, the slides was immersed in lysis solution [2.5M NaCl, 0.1 M EDTA, 
$0.01 \mathrm{M}$ Tris, $1 \%$ Triton X-100 and 10\% DMSO (pH 10.0)] for more than $2 \mathrm{hrs}$ at $4^{\circ} \mathrm{C}$ under dark condition. To unwind DNA, the slides were placed on an electrophoresis tank containing electrophoresis buffer [ $10 \mathrm{~N} \mathrm{NaOH}$ and $0.2 \mathrm{M} \mathrm{Na}_{2} \operatorname{EDTA}(\mathrm{pH} 13.0)$ ] for $20 \mathrm{~min}$ at $4^{\circ} \mathrm{C}$. Electrophoresis was performed at $25 \mathrm{~V} / 0.3 \mathrm{~A}$ for $20 \mathrm{~min}$ at $4^{\circ} \mathrm{C}$. The slides were washed with neutralizing buffer $[0.4 \mathrm{M}$ Tris $\cdot \mathrm{HCl}(\mathrm{pH} 7.5)]$ three times for $5 \mathrm{~min}$ at $4^{\circ} \mathrm{C}$ and fixed with crude ethanol for $5 \mathrm{~min}$. The slides were then air dried for 15 min, and stored in slide box at $4^{\circ} \mathrm{C}$. The entire electrophoresis prosess was carried out in dark.

Image analysis: The slides were stained with ethidium bromide and the fluorescence was measured using a fluorescence microscope (Leica, Wetzlar, Germany) in dark condition and viewed with a CCD camera (Hitachi, Japan). The captured image was analyzed using Komet 5.5 software (Kinetic Imaging, UK) DNA damage was quantified via comet assay, wherein the olive tail moment was calculated by the formula: (Tail. mean-Head. mean) $x$ Tail\% DNA / 100. A total of 100 lymphocytes were randomly captured and the comets were examined from each slide. All measurements were made in duplicate and performed from three independent experiments.

Cell culture: Human lung cancer cell (A549) was obtained from the American Type Culture Collection (ATCC, Rockville, USA). Cells were maintained in RPMI-1640 [with $10 \%$ fetal bovine serum (FBS) and $1 \%$ penicillin-streptomycin (PS)] in a humidified atmosphere containing $5 \% \mathrm{CO}_{2}$ at $37^{\circ} \mathrm{C}$.

MTT cell viability assay: A549 cell viability was measured by 3 [4,5-dimethylthiazol-2-yl]-2,5 diphenyl tetrazolium bromide

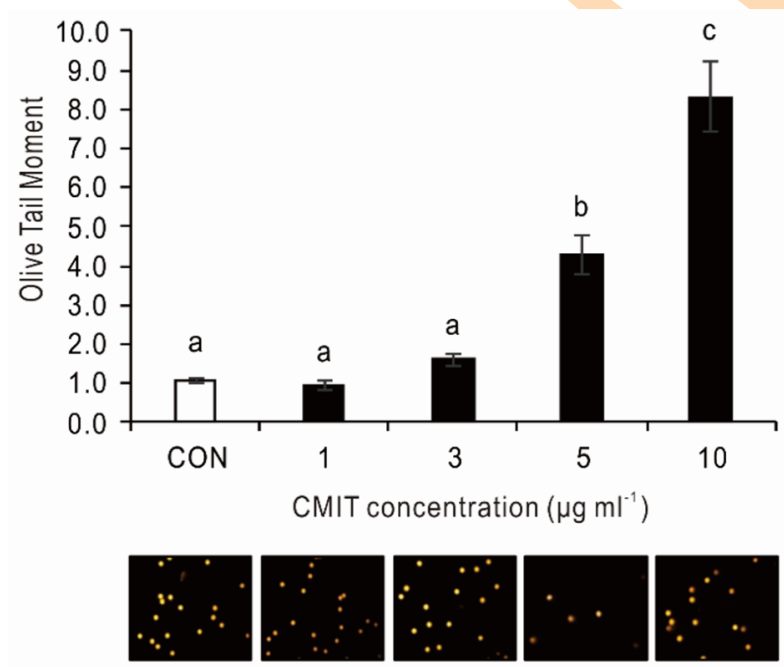

Fig. 1: CMIT-induced oxidative DNA damage measured by comet assay. Values not sharing the same letter are significantly different from one another $(p<0.05)$ according to Duncan's Multiple Range Test.
(MTT) assay. The cells were cultured in 96-well plated at a density of $1 \times 10^{4}$ cells per well. The cells were then treated with varying concentration of CMIT for $24 \mathrm{hrs}$. The cells were washed and treated with $50 \mu \mathrm{l}$ of MTT, after which the plates were incubated at $37^{\circ} \mathrm{C}$ in dark for $3 \mathrm{hrs}$. After the formation of formazan, $50 \mu \mathrm{l}$ of DMSO was added and the absorbance was read at $570 \mathrm{~nm}$ using a microtiter plate reader. A549 cells were treated with $10 \mathrm{\mu g} \mathrm{ml}^{-1}$ of CMIT, and then $1 \sim 7 \mu \mathrm{g} \mathrm{ml}^{-1}$ of Vitamin C, curcumin, resveratrol and berberine were directly added to the A549 cells in order to assess measure the protection against CMIT-induced cytotoxicity.

Statistics: All experiments were carried out in triplicate and analyzed using SPSS package for Windows version 13 (SPSS Inc., Chicago, IL). The analytical data were presented as mean \pm $\mathrm{SD}$. The results from each treatment of CMIT and phytochemicals were compared with each other using one-way analysis of variance (ANOVA) followed by Duncan's Multiple Range Test. $p<$ 0.05 was considered significant.

\section{Results and Discussion}

The information on the toxicity of CMIT/MIT mixture and individual component is limited, although the toxicity and reactivity of CMIT has been reported to be more potent than MIT (Cho et al., 2017). The carcinogenicity of CMIT was ruled out by IARC (Kahrilas et al., 2014), but chronic and high exposure can cause a detrimental effect at DNA and cellular level. Based on the earlier findings of in-vitro genotoxicity for humidifier disinfectant (Kim and Paek, 2016), DNA damage via comet assay and its protection by phytochemicals were investigated in this study. The general toxicity triggered by chemicals can be detected by

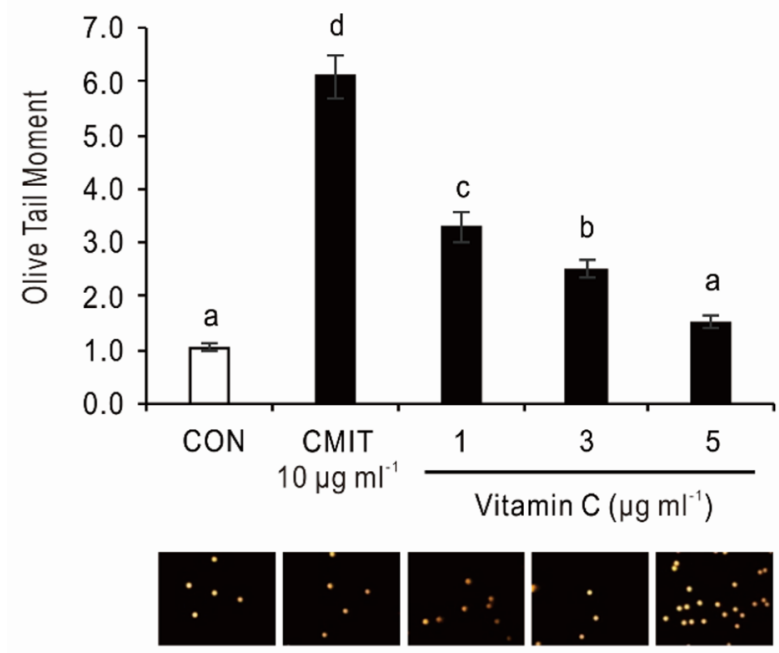

Fig. 2: Suppressive effect of Vitamin C on CMIT-induced oxidative DNA damage. Values not sharing the same letter are significantly different from one another $(p<0.05)$ according to Duncan's Multiple Range Test. 
enhanced levels of reactive oxygen species (ROS), proinflammatory cytokines and oxidative metabolic enzymes (Xiao et al., 2017). ROS induces the expression of NF-KB, a key transcription factor in the inflammatory response, as well as a variety of proteins linked with oxidative stress-associated reactions. In addition, phytochemicals with antioxidant activity, such as carotenoid (Caramujo et al., 2012) and polyphenols including phenolic acids (Sevgi et al., 2015), flavonoids (Manzolli et al., 2015) and stilbenes (Biais et al., 2017), have been extensively used to reduce toxicity triggered by toxic chemicals.

Fig. 1 shows the degree of oxidative DNA damage in lymphocytes of rats treated with $1,3,5$ and $10 \mu \mathrm{g} \mathrm{ml}^{-1}$ of CMIT. DNA damage was enhanced in proportion to the CMIT concentrations with statistical significance $(p<0.05)$. The olive tail moment was 1.1 in the control group treated with PBS, however, the olive tail moment at $10 \mu \mathrm{g} \mathrm{ml}^{-1} \mathrm{CMIT}$ was about 7.5 -fold higher than the control group. However, as shown in Fig. 2, the enhanced olive tail moment by $10 \mu \mathrm{g} \mathrm{ml}^{-1} \mathrm{CMIT}$ decreased sharply upon treatment with Vitamin C. Especially, $5 \mu \mathrm{g} \mathrm{ml}^{-1}$ of Vitamin $\mathrm{C}$ was very close to i.e., 1.0. These results show that Vitamin $\mathrm{C}$ might inhibit oxidative DNA damage by CMIT, probably due to quenching of superoxide and hydroxyl radicals. These results also suggest that DNA damage caused by CMIT might be linked to generation of reactive oxygen species (ROS) (Ettorre et al., 2003), although CMIT's mode of action against DNA structure has not been fully elucidated yet. There are many reports that phytochemicals play pivotal roles in blunting the toxicity induced by chemicals or environmental factors. Antioxidants including resveratrol and curcumin have been effective in reducing acrylamide toxicity in cell lines and/or animal studies, via anti-oxidative, anti-apoptotic, anti-inflammatory and
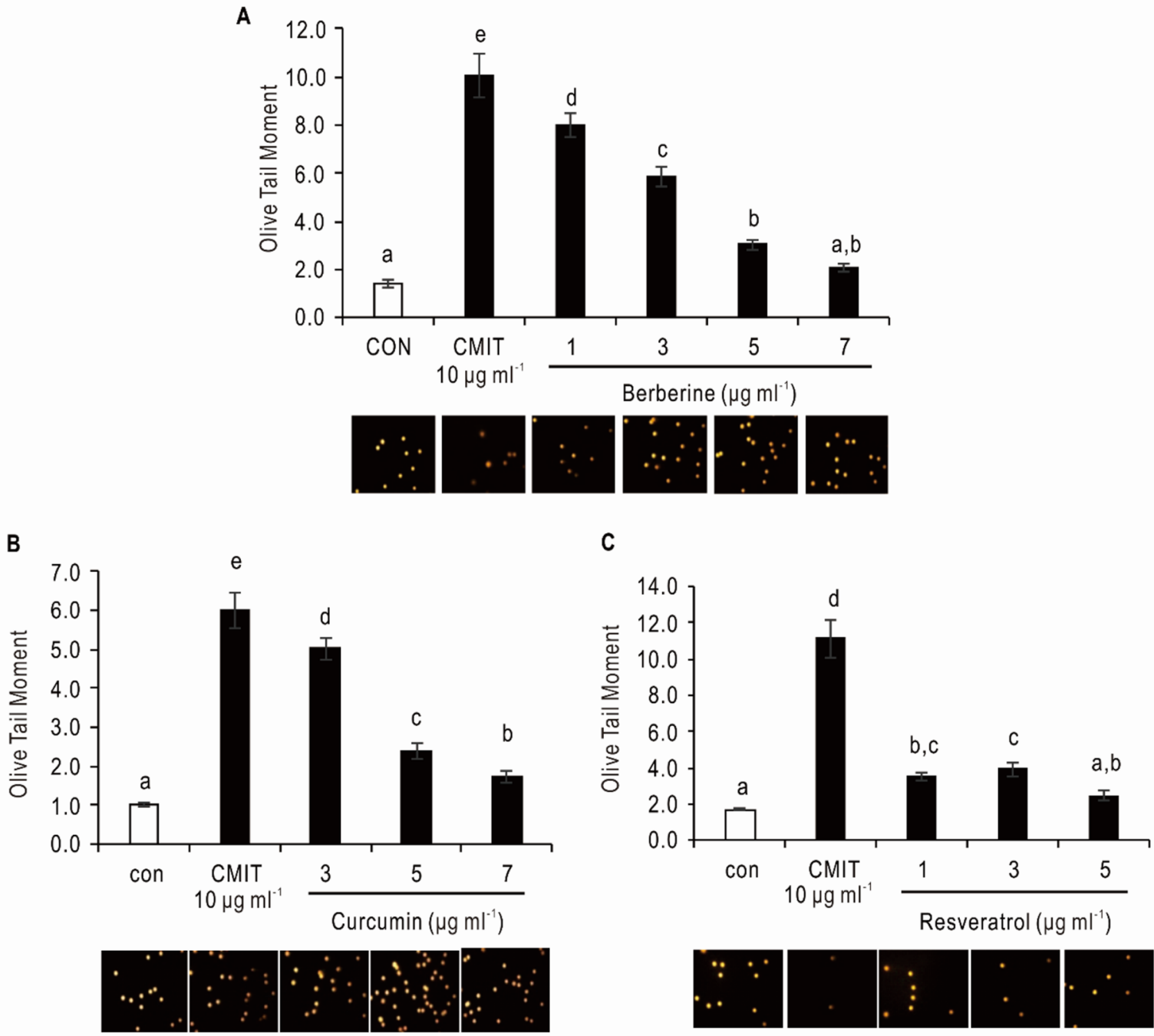

Fig. 3: Suppressive effect of (A) Berberine, (B) Curcumin and (C) Resveratrol on CMIT-induced oxidative DNA damage. Values not sharing same letter are significantly different from one another $(p<0.05)$ according to Duncan's Multiple Range Test. 
reduction of chemical absorption (Kahkeshani et al., 2015). Also, curcumin, berberine and sulforaphane prevented the oxidative DNA damage progression by chrysotile (Ryu et al., 2012), hydrofluoric acid (Seo and Lee, 2013) and nano sized $\mathrm{TiO}_{2}$ (Ryu et al., 2016; Valentini et al., 2017). Four different phytochemicals from edible plants such as auraptene, nobiletin, zerumbone and ( \pm )-13-hydroxy-10-oxo-trans-11-octadecenoic acid was effective in reversing the inflammatory action by dioxine in U937 human macrophages (Sciullo et al., 2010).

The inhibitory effect of berberine on CMIT-induced DNA damage in lymphocytes is shown in Fig. $3 A$. The olive tail moment of CMIT alone was 9.8, however, 1, 3, 5 and $7 \mathrm{\mu g} \mathrm{m}^{-1}$ berberine treatment reduced $18 \%, 41 \%, 70 \%$ and $80 \%$ olive tail moment induced by CMIT, respectively. Especially, at $7 \mathrm{\mu g} \mathrm{ml}^{-1}$ berberine, olive tail moment showed a low level similar to that of CMIT-treated control group. Berberine, a major component of shrub Berberis vulgaris, has been reported to have antioxidant (Kim et al., 2016), anti-inflammatory (Tsang et al., 2016), antibacterial (Peng et al., 2015), antihypertensive (Guo et al., 2015), antitumor (Goto et al., 2014) and anxiolytic activity (Peng et al., 2004). The results of this paper also suggest that berberine may act as an antioxidant to quench reactive oxygen species generated by CMIT treatment.

The olive tail moment of CMIT alone was 6.0, however, 3 , 5 and $7 \mu \mathrm{g} \mathrm{m}^{-1}$ curcumin treatment reduced approximately $10 \%$, $60 \%$ and $72 \%$ of olive tail moment, respectively (Fig. 3B). The olive tail moment of curcumin-treated group decreased in a dosedependent mode. Tumeric has curcuminoid compounds such as curcumin, demethoxycurcumin, and bisdemethoxycurcumin. Of these, curcumin plays an important role as an antioxidant (Xu et al., 2018), analgesic (Chin et al., 2016) and anti-inflammatory agent (Wilken et al., 2011). Resveratrol is a typical phytochemical exist inmany edible plants including peanuts, grapes and berries. The activities of resveratrol such as anti-oxidant, anti-cancer, antiviral and anti-inflammatory activity have been examined in a variety of in vivo and in vitro studies (Gambini et al., 2015). Resveratrol, as an efficient antioxidant with free radical scavenger activity, enhanced and/or maintained the level of several antioxidant enzymes, including superoxide dismutase, catalase, glutathione reductase and glutathione peroxidase. However, the direct scavenging activities of resveratrol are yet not clarified. Some of the gene-regulating effects of resveratrol has been reported to be medicated by the histone/protein deacetylase sirtuin 1 or by the nuclear factor-E2-related factor-2 (Xia et al., 2017). As shown in Fig. 3C, DNA damaged by $10 \mu \mathrm{g} \mathrm{ml}^{-1} \mathrm{CMIT}$ showed an olive tail moment of $11.1 \pm 2.16$, however, approximately $70 \%$ reduction of the olive tail moment was obtained at $1,3,5 \mu \mathrm{g} \mathrm{ml}^{-1}$ of resveratrol. These data indicated that all doses of resveratrol used here reduced DNA damage similar to the control level. Taken together, resveratrol might be the most superior inhibitor against CMIT toxicity assessed in Comet system.

Finally, the cell viability of A549 was measured with or without resveratrol under CMIT toxicity. As shown in Fig. 4, about

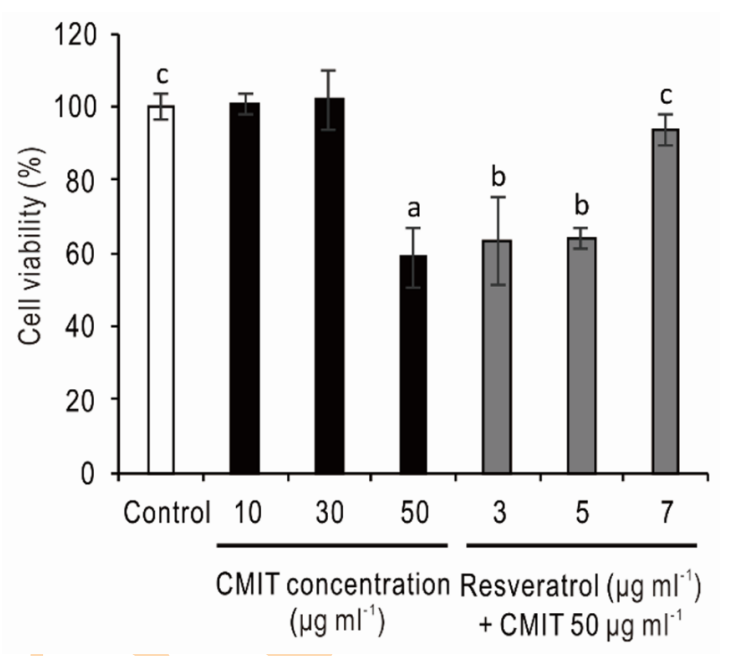

Fig. 4: The protective effect of resveratrol on CMIT-induced cytotoxicity. Values not sharing same letter are significantly different from one another $(p<0.05)$ according to Duncan's Multiple Range Test.

$41.3 \%$ of the cells died as compared to control at $50 \mu \mathrm{g} \mathrm{ml}^{-1} \mathrm{CMIT}$, whereas no cytotoxicity was observed from 10 to $40 \mu \mathrm{g} \mathrm{ml}^{-1} \mathrm{CMIT}$. Cells treated with 3 and $5 \mu \mathrm{g} \mathrm{ml}^{-1}$ of resveratrol did not prevent the cell death by CMIT. However, treatment with $7 \mu \mathrm{g} \mathrm{ml}{ }^{-1}$ of resveratrol showed similar level of cell survival as that of control group. In Fig. 3C, lymphocytes treated with 3 and $5 \mu \mathrm{gll}^{-1}$ resveratrol showed protective effect against $10 \mathrm{\mu g} \mathrm{ml}^{-1}$ CMIT toxicity. These results suggest that Comet assay with DNA damage is more sensitive than MTT assay with cytotoxicity in measuring CMIT toxicity. Further, protective studies against cytotoxicity by CMIT are being performed in various systems with various phytochemicals.

In conclusion, Vitamin $\mathrm{C}$, and curcumin, berberine and resveratrol have in-vitro protective effects against CMIT-induced lymphocyte DNA damage. In addition, the lowest concentration of resveratrol showed the highest protective effect against DNA damage, and inhibited CMIT cytotoxicity at cellular level. The preventive effect of selected phytochemicals against DNA damage and cytotoxicity due to CMIT may be applied for the development of anti-CMIT agent.

\section{Acknowledgment}

This study was supported by Soonchunhyang University.

\section{References}

Biais, B., S. Krisa, S. Cluzet, G. Da Costa, P. Waffo-Teguo, J.M. Mérillon and T. Richard: Antioxidant and cytoprotective activities of grapevine stilbenes. J. Agric. Food. Chem., 65, 4952-4960 (2017).

Botham, P.A., J. Hilton, C.D. Evans, D. Lees and T.J. Hall: Assessment of the relative skin sensitizing potency of 3 biocides using the murine local lymph node assay. Contact. Dermatitis, 25, 172-177 (1991). 
Caramujo, M.J., C.C de Carvalho, S.J. Silva and K.R. Carman: Dietary carotenoids regulate astaxanthin content of copepods and modulate their susceptibility to UV light and copper toxicity. Mar. Drugs., 10, 998-1018 (2012)

Chin, K.Y.:The spice for joint inflammation: Anti-inflammatory role of curcumin in treating osteoarthritis. Drug. Des. Devel. Ther., 10 3029-3042 (2016).

Cho, H.J., D.U. Park, J. Yoon, E. Lee, S.I. Yang, Y.H. Kim, S.Y. Lee and S.J. Hong: Effects of a mixture of chloromethylisothiazolinone and methylisothiazolinone on peripheral airway dysfunction in children. PLoS One, 12, e25436 (2017).

Collins, A.R.: The comet assay for DNA damage and repair: Principles, applications, and limitations. Mol. Biotechnol., 26, 249-261 (2014).

Connor, T.H., P.G. Tee, M. Afshar and K.M. Connor: Mutagenicity of cosmetic products containing Kathon. Environ. Mol. Mutagen., 28 127-132(1996).

Ettorre, A., M. Andreassi, C. Anselmi, P. Neri, L. Andreassi and A. Di Stefano: Involvement of oxidative stress in apoptosis induced by a mixture of isothiazolinones in normal human keratinocytes. $J$. Invest. Dermatol.,121, 328-336 (2003).

Frenzel, E., S. Schmidt, M. Niederweis and K. Steinhauer: Importance of porins for biocide efficacy against Mycobacterium smegmatis. Appl. Environ. Microbiol.,77, 3068-3073 (2011).

Gambini, J., M. Inglés, G. Olaso, R. Lopez-Grueso, V. Bonet-Costa, L. Gimeno-Mallench, C. Mas-Bargues, K.M. Abdelaziz, M.C. Gomez-Cabrera, J. Vina and C. Borras: Properties of resveratrol: In vitro and in vivo studies about metabolism, bioavailability, and biological effects in animal models and humans. Oxid. Med. Cell. Longev., 2015, 837042 (2015)

Goto, H., R. Kariya, M. Shimamoto, E. Kudo, M. Taura, H. Katano and S. Okada: Antitumor effect of berberine against primary effusion lymphoma via inhibition of NF-kB pathway. Cancer Sci.,103, 775 $781(2014)$

Guo, Z., H. Sun, H. Zhang and Y. Zhang: Anti-hypertensive and renoprotective effects of berberine in spontaneously hypertensive rats. Clin. Exp. Hypertens., 37, 332-339 (2015).

He, K., J. Huang, C.F. Lagenaur and E. Aizenman: Methylisothiazolinone, a neurotoxic biocide, disrupts the association of src family tyrosine kinases with focal adhesion kinase in developing cortical neurons. J. Pharmacol. Exp. Ther., 317,1320-1329 (2006).

Kahkeshani, N., S. Saeidnia and M. Abdollahi: Role of antioxidants and phytochemicals on acrylamide mitigation from food and reducing its toxicity. J. Food. Sci. Technol., 52, 3169-3186 (2015).

Kahrilas, G.A., J. Blotevogel, P.S. Stewart and T. Borch: Biocides in hydraulic fracturing fluids: A critical review of their usage, mobility, degradation, and toxicity. Environ. Sci. Technol., 49, 16-32 (2014).

Kim, H.Y., Y.H. Chung and Y.C. Park: Intra-tracheal administration of the disinfectant chloromethylisothiazolinone/methylisothiazolinone (CMIT/MIT) in a mouse model to evaluate a causal association with death. J. Environ. Hlth. Sci., 43, 247-256 (2017).

Kim, J.H., A.R. Ryu, M.J. Kang and M.Y. Lee: Berberine-induced changes in protein expression and antioxidant enzymes in melanoma cells. Mol. Cell. Toxicol.,12, 53-61 (2016).

Kim, S. and D. Paek: Humidifier disinfectant disaster: What is known and what needs to be clarified. Environ. Hlth. Toxicol., 31, e2016025 (2016).

Kirkland, D., S. Pfuhler, D. Tweats, M. Aardema, R. Corvi, F. Darroudi, A Elhajouji, H. Glatt, P. Hastwell, M. Hayashi, P. Kasper, S. Kirchner, A. Lynch, D. Marzin, D. Maurici, J.R. Meunier, L. Müller, G. Nohynek, J. Parry, E. Parry, V. Thybaud, R. Tice, J. van Benthem, $P$. Vanparys and P. White: How to reduce false positive results when undertaking in vitro genotoxicity testing and thus avoid unnecessary follow-up animal tests: Report of an ECVAM Workshop. Mutat. Res., 628, 31-55 (2007).

Maio, P., R. Carvalho, C. Amaro, R. Santos and J. Cardoso: Contact allergy to methylchoroisothiazolinone/methylisothiazolinone (MCl/MI): Findings from a contact dermatitis unit. Cutan. Ocul. Toxicol., 31, 151-153 (2012).

Manzolli, E.S., J.M. Serpeloni, D. Grotto, J.K. Bastos, L.M. Antunes, F. Barbosa Junior and G.R. Barcelos: Protective effects of the flavonoid chrysin against methylmercury-induced genotoxicity and alterations of antioxidant status, in vivo. Oxid. Med. Cell. Longev., 2015, 602360 (2015)

Nagorka, R., C. Gleue, C. Scheller, H.J. Moriske and W. straff: Isothiazolone emissions from building products. Indoor Air, 25, 6878 (2015).

Park, E.J., S. Kim S and J. Chang: Methylisothiazolinone may induce cell death and inflammatory response through DNA damage in human liver epithelium cells. Environ. Toxicol., 33, 156-166 (2018).

Pelletier, G., V.E. Valli, M. Rigden and R. Poon: Effects of a 28-day oral exposure to a 5-chloro-2-methyl-4-isothiazolin-3-one and 2methyl-4-isothiazolin-3-one biocide formulation in SpragueDawley rats. Drug. Chem. Toxicol., 37, 149-155 (2014).

Peng, L., S. Kang, Z. Yin, R. Jia, X. Song, L. Li, Z. Li, Y. Zou, X. Liang, L. Li, C. He, G. Ye, L. Yin, F. Shi, C. Lv and B. Jing: Antibacterial activity and mechanism of berberine against Streptococcus agalactiae. Int. J. Clin. Exp. Pathol., 8, 5217-5223 (2015).

Peng, W.H., C.R. Wu, C.S. Chen, C.F. Chen, Z.C. Leu and M.T. Hsieh: Anxiolytic effect of berberine on exploratory activity of the mouse in two experimental anxiety models: Interaction with drugs acting at 5-HT receptors. Life Sci., 75, 2451-2462 (2004).

Poon, R., M. Rigden, N. Edmonds, N. Charman and S. Lamy: Effects of 5-chloro-2methyl-4-isothiazolin-3-one and other candidate biodiesel biocides on rat alveolar macrophages and NR8383 cells. Arch. Toxicol., 85, 1419-1427 (2011)

Potter, D.W. and G.A. Hazelton: Evaluation of auricular lymph node cell proliferation in isothiazolone-treated mice. Fundam. Appl. Toxicol., 24, 165-172 (1995)

Ryu, A.R., I.C. Bang, S.A. Lee and M.Y. Lee: The protective role of phytochemicals on $\mathrm{TiO}_{2}$ nanoparticles-induced DNA damage in lymphocytes. J. Environ. Biol., 37, 913-917 (2016).

Ryu, A.R., J.J. Kim and M.Y. Lee: The inhibitory effect of phytochemicals on the oxidative DNA damage in lymphocytes by chrysotile. $J$. Appl. Biol. Chem., 55, 179-184 (2012)

Sciullo, E. M., C. F. Vogel, D. Wu, A. Murakami, H. Ohigashi and F. Matsumura: Effects of selected food phytochemicals in reducing the toxic actions of TCDD and p, $p^{\prime}$-DDT in U937 macrophages. Arch. Toxicol., 84, 957-966 (2010)

Seo, E.J. and M.Y. Lee: Amelioration of hydrofluoric acid-induced DNA damage by phytochemicals. Toxicol. Environ. Hlth. Sci., 5, 201. 206 (2013)

Sevgi, K., B. Tepe and C. Sarikurkcu C: Antioxidant and DNA damage protection potentials of selected phenolic acids. Food. Chem. Toxicol., 77, 12-21 (2015)

Singh, N.P., M.T. McCoy, R.R. Tice and E.L. Schneider: A simple technique for quantitation of low levels of DNA damage in individual cells. Exp. Cell Res., 175, 184-191 (1988).

Tsang, M.S., D. Jiao, B.C. Chan, K.L. Hon, P.C. Leung, C.B. Lau, E.C. Wong, L. Cheng, C.K. Chan, C.W. Lam and C.K. Wong: Antiinflammatoryactivities of pentaherbs formula, berberine, gallicacid and chlorogenicacid in atopic dermatitis-like skin inflammation. Molecules, 21,519 (2016).

Upadhyay, S. and M. Dixit: Role of polyphenols and other phytochemicals on molecular signaling. Oxid. Med. Cell. Longev., 2015, $504253(2015)$ 
Valentini, X., L. Absil, G. Laurent, A. Robbe, S. Laurent, R. Muller, A. Legrand and D. Nonclercq: Toxicity of $\mathrm{TiO}_{2}$ nanoparticles on the NRK52E renal cell line. Mol. Cell. Toxicol., 13, 419-431 (2017).

Wilken, R., M.S. Veena, M.B. Wang and E.S. Srivatsan: Curcumin: A review of anti-cancer properties and therapeutic activity in head and neck squamous cell carcinoma. Mol. Cancer, 10 (2011). doi: 10.1186/1476-4598-10-12.

Xia, N., A. Daiber, U. Förstermann and H. Li: Antioxidant effects of resveratrol in the cardiovascular system. Br. J. Pharmacol., 174,
1633-1646 (2017)

Xiao, T.J., S. Li, Y.L. Xiang, Q. L.Hang, C. Long and Y.L. Zhuo: Protective effects of vitamins $C$ and $E$ on dichlorodiphenyltrichloroethaneinduced genotoxicity and hepatotoxicity in human liver cells. Mol. Cell. Toxicol., 13, 155-164 (2017).

Xu, X.Y., X.Meng, S. Li, R.Y. Gan, Y. Li and H.B. Li: Bioactivity, health benefits, and related molecular mechanisms of curcumin: Current progress, challenges and perspectives. Nutrients, 10, 1553 (2018). 